\title{
TSPAN3 Gene
}

National Cancer Institute

\section{Source}

National Cancer Institute. TSPAN3 Gene. NCI Thesaurus. Code C131276.

This gene plays a role in receptor signaling pathways. 